\title{
O paradoxo cristológico: A proposta de Claude Geffré para o diálogo inter-religioso
}

Carlos Antonio da Silva

\section{Introdução}

Este estudo aprofundará os fundamentos cristológicos que Claude Geffré utiliza para construir sua teologia das religiões. Já que o pluralismo religioso é uma clara evidência, urge um sincero esforço de entendê-lo teologicamente. O Concílio Vaticano II abriu um caminho promissor para uma consideração positiva do atual contexto pluricultural e pluri-religioso. Ao considerar positivamente a história como lugar da automanifestação de Deus, o Concílio permitiu ao mesmo tempo que se considerassem outras formas possíveis desse permanente advento de Deus, na história humana. É certo que a singularidade de Jesus Cristo, como a revelação plena de Deus, é um dado irrenunciável para o cristianismo. No entanto, mesmo essa pretensão cristã não pode ser um obstáculo intransponível para um diálogo fecundo com as grandes religiões do mundo. A reflexão teológica de Geffré pode contribuir para uma compreensão melhor dessa questão. É possível deixar de considerar Jesus Cristo como um "entrave" para o diálogo com as outras religiões. Uma adequada compreensão da fé cristã na Encarnação do Verbo pode ser a chave hermenêutica para o diálogo inter-religioso e não o contrário.

\section{A única mediação de Cristo diante das outras tradições religiosas}

A situação atual de pluralismo religioso coloca um desafio para todas as religiões. No entanto, esse desafio se torna crucial para uma religião como o 
cristianismo que durante muito tempo compreende-se como absoluta e universal. ${ }^{1} \mathrm{O}$ cristianismo não pode, de per si, se comparar a nenhuma outra religião porque se define a partir do Evangelho, que, por sua vez, é compatível com qualquer código religioso que pretenda ser agradável a Deus. ${ }^{2} \mathrm{O}$ contexto cultural pluralista hodierno pede uma atitude de respeito e de diálogo por parte da toda teologia cristã. Esse é um desafio que não pode ser despistado, mas encarado corajosamente.

No final do século XIX e no início do século XX, a Igreja experimentou um grande influxo missionário. Um grande otimismo começou a tomar conta de todas as instâncias eclesiais. A possibilidade real de chegar a todos os quadrantes da terra levou ao surgimento de uma expectativa real da vitória da fé cristã sobre as demais tradições religiosas. Ocorre que, já nos últimos anos do século passado e no início do nosso, as outras grandes tradições religiosas do mundo mostraram um surpreendente vigor. Isso não vale apenas para o Islã, que continua sua expansão vertiginosa na África, na Ásia e em alguns países da Europa Ocidental. Também as religiões de matriz oriental experimentam um crescimento não desprezível, ampliando sua presença em sociedades consideradas até então secularizadas e materialistas como alguns países da Europa e da América do Norte.

Nesse contexto, o diálogo inter-religioso não pode ser apenas um apêndice, mas uma dimensão necessária à teologia cristã. A palavra "diálogo" não pode ser mais usada apenas como um "slogan", mas com a seriedade suscitada pelas novas questões colocadas à reflexão teológica. ${ }^{3}$ Subsiste uma tensão fundamental entre as exigências de igualdade e de reciprocidade de todo verdadeiro diálogo e a pretensão legítima do cristianismo como religião da manifestação absoluta e definitiva de Deus em Jesus Cristo. Para o cristianismo sempre será inaceitável considerar Cristo como um mediador entre os outros e não como a manifestação definitiva de Deus a toda a humanidade.

Claude Geffré contribui originalmente para esse debate buscando uma resposta teologicamente adequada a essa dificuldade concreta: como considerar positivamente o diálogo, sem sacrificar a identidade cristã? Ele não considera suficiente apenas passar do cristocentrismo ao teocentrismo como defendem alguns teólogos pluralistas. ${ }^{4}$ Sem abrir mão da normatividade da cristolo-

\footnotetext{
${ }^{1}$ GEFFRE, C. "La singularité du christianisme à l'âge du pluralisme religieux", art. cit., p. 351.

2 Id. "Théologie chrétienne et dialogue interreligieux", In: Revue de l'Institut Catholique de Paris, n $^{\circ} 38,1991$, p. 80.

${ }^{3}$ GEFFRE, C. "La singularité du christianisme à l'âge du pluralisme religieux", art. cit., p. 351.

${ }^{4}$ Como John Hick, por exemplo, especialmente no capítulo 2 do livro organizado em colaboração com Paul Knitter cujo título é L'unicità cristiana: un mito? Per una teologia pluralista delle religioni. Assisi: Cittadella Editrice, 1994, p. 80-110. Também em A metáfora do Deus encar-
} 
gia, Geffré sustenta que é possível partir do centro mesmo da fé cristã, a saber, a manifestação de Deus na particularidade histórica de Jesus de Nazaré, crucificado e confessado como o Cristo, para tirar a prova do caráter necessariamente dialogal do cristianismo. Então, afirmar a centralidade de Jesus, longe de obstaculizar o diálogo, viabiliza-o, na medida em que a prática do diálogo leva ao aprofundamento da própria identidade cristã que, por sua vez, se configurará sempre mais em termos não totalitários.

\subsection{Cristianismo e pluralismo religioso}

O teólogo francês busca demonstrar sua tese fundamental a partir de alguns argumentos chave. $\mathrm{O}$ primeiro deles considera nossa situação atual marcada, segundo ele, pela necessidade de um "ecumenismo planetário". A aproximação real das religiões e a necessária convivência entre elas leva, inevitavelmente, a teologia a considerar adequadamente a pluralidade das experiências religiosas. Geffré diz que esse contexto corresponde à evolução de nossa cultura ocidental, que não está somente sob o signo do ateísmo ou do indiferentismo religioso, mas também sob o influxo cada vez maior de múltiplas experiências religiosas. Contrariando previsões quase consensuais, a religião não desapareceu. Ao contrário, ocupa amplos e mesmo surpreendentes espaços na sociedade. ${ }^{5}$ Esse novo contexto leva-o a usar a expressão "ecumenismo planetário", alargando o sentido normalmente dado à palavra "ecumenismo", como uma referência ao diálogo entre as diversas confissões cristãs. Um ecumenismo planetário se adequaria melhor ao que experimentamos hoje: o diálogo entre as religiões coincide com uma consciência mais viva da unidade da família humana (a oikoumene - a terra habitada) e com um sentido mais agudo da responsabilidade comum das grandes religiões quanto ao futuro do ser humano. Esse alargamento do sentido da palavra "ecumenismo" à escala planetária não significa, em absoluto, uma redução da urgência da concretização da unidade entre os cristãos.

$\mathrm{O}$ segundo argumento de Geffré diz respeito ao reconhecimento de um pluralismo religioso de princípio. O pluralismo inevitável que percebemos é

nado. Petrópolis, Vozes, 2000, p. 123-135. Em termos semelhantes no livro: Teologia cristã e pluralismo religioso. São Paulo: Attar Editorial/PPCIR, 2005, especialmente os capítulos 4 e 5. Também Raimundo Panikkar, Il dialogo intrareligioso. Assisi: Cittadella Editrice, 1988, em especial nas páginas 70-93. Paul Knitter também se posiciona por uma cristologia transcendental ou teocêntrica em Nessun altro nome? Un esame critico degli attegiamenti cristiani verso le religioni mondiali. Brescia: Queriniana, 1991, p. 125-195; da mesma forma em Una terra molte religioni. Dialogo interreligioso e responsabilità globale. Assisi: Citadella Editrice, 1998, p. 70.

${ }^{5}$ GEFFRE, C. "La singularité du christianisme à l'âge du pluralisme religieux", art. cit., p. 352. 
mais um elemento da nova consciência histórica que temos hoje e que nos leva ao desafio de uma interpretação diferente da verdade do cristianismo. Aqui Geffré insiste num pluralismo já contido no que chamamos desígnio de Deus, e não apenas fruto das condições sócio-culturais de hoje. ${ }^{6}$ Durante séculos o cristianismo interpretou sua própria verdade e sua unicidade como uma reivindicação de absoluto. Essa visão considerava as outras religiões como 'naturalmente' menores. Se algo de bom ou verdadeiro elas tivessem, isso seria compreendido em termos eminentemente cristãos. Isso se acentuou, sobretudo, depois dos êxitos da empresa colonial do século XVI.

Outro complicador é que a Bíblia não nos ajuda muito a descobrir o pluralismo religioso no desígnio de Deus. A diversidade das línguas e das culturas aparece sob o signo da ambiguidade, como o revela o mito de Babel. Como diz o Vaticano II, as divergências entre as religiões podem ser expressões dos limites humanos e das influências do espírito do mal na história (LG 16). Mas também podem exprimir o gênio e as riquezas espirituais dispensadas por Deus às diversas nações (AG 11). Por isso, um critério fundamental para a hermenêutica do diálogo inter-religioso é a afirmação da vontade salvífica universal de Deus que se estende a todos os seres humanos (1Tm 2, 4-6; At 10, 34-35). A partir desses elementos, é que se pode falar da possibilidade do pluralismo religioso ser um destino histórico permitido por Deus, cuja significação última nos escapa. Mesmo a despeito dos seus limites, as múltiplas formas religiosas surgidas na longa história da humanidade podem estar a serviço de uma melhor manifestação da plenitude inexaurível do Espírito de Deus. ${ }^{7}$

A grande dificuldade para a aceitação positiva do diálogo inter-religioso vem justamente do fato de que este justapõe dois princípios irrenunciáveis: a fé na vontade salvífica universal de Deus e a unicidade da mediação de Cristo. Ora, o Concílio de Florença (1442) declarou solenemente que não somente os pagãos, mas os judeus, os heréticos, os cismáticos, não podem ter parte na vida eterna (DS 1351). Uma leitura contextualizada desse texto revela que a experiência histórica que os Padres conciliares viviam naquela ocasião levava-os a não imaginar, sob nenhuma hipótese, outro caminho de salvação fora do cris-

\footnotetext{
${ }^{6}$ GEFFRE, C. "La singularité du christianisme à l'âge du pluralisme religieux", art. cit., p. 353. Aqui o autor apresenta na nota de pé de página $\mathrm{n}^{\circ} 1$ a influência teológica decisiva que sofreu de E. Schillebeeckx na obra L'Histoire des hommes, récit de Dieu. Paris: Cerf, 1992. Destaca especialmente como o terceiro capítulo o ajudou no que se refere à distinção entre pluralismo de fato e pluralismo de princípio.

${ }^{7}$ Id. Ibid., p. 354. Aqui o autor faz referência a João Paulo II no discurso à Cúria Romana sobre o espírito de Assis, proferido em 22 de dezembro de 1986. Disponível em:

http://www.vatican.va/holy_father/john_paul_ii/speeches/1986/december/documents/hf_jpii_ spe_19861222_curia-romana_it.html Acesso em 27/03/2008.
} 
tianismo. Por isso, rejeitaram espontaneamente o que não era cristão. Nós, no entanto, não podemos mais sucumbir ao equívoco de confundir nossa autêntica experiência pessoal de fé com uma verdade objetivamente absoluta. Essa afirmação soa impensável hoje justamente devido à nossa consciência histórica, que é diversa da que existia no século XV. Nós também nos definimos como cristãos. Por isso, é tarefa nossa conciliar, a partir da mentalidade do nosso tempo, a confissão central de nossa fé: em Jesus Cristo habitou corporalmente a plenitude da divindade $(\mathrm{Cl} 2,9)$. Como conciliar a manifestação de Deus na particularidade histórica de Jesus de Nazaré sem fechar a possibilidade de outras manifestações de Deus na história?

Nossa interpretação dos textos do Novo Testamento e da Tradição patrística precisa considerar a experiência histórica de pluralismo que se vive hoje. Estamos em um contexto radicalmente diferente. Nós não podemos imaginar a reação dos Padres da Igreja, por exemplo, diante de uma religião como o Islã. Em todo caso, a genial intuição patrística das "Sementes do Verbo" continua com uma atualidade impressionante para que possamos considerar positivamente as religiões não-cristãs sem colocar em questão a normatividade da revelação cristã. ${ }^{8}$

O diálogo inter-religioso apresenta uma tarefa difícil e inédita: pensar a inevitável pluralidade de caminhos que levam a Deus, sem renunciar à singularidade cristã. É preciso levar a sério as conseqüências desse pluralismo. $\mathrm{O}$ caminho está aberto.

\subsection{Critérios básicos para o diálogo inter-religioso}

Geffré defende que o cristianismo tem, desde suas origens, uma abertura para o diálogo com as diferenças. São três os critérios para o diálogo apresentados por ele:

$1^{\circ}$. Respeitar o outro em sua diferença. Deveríamos recordar sempre que o reconhecimento do estrangeiro está na raiz da tradição judaico-cristã. É preciso distinguir um diálogo que cultive a diferença, de um que tenda à assimilação. A tradição bíblica coloca o princípio de que o dessemelhante reconhece o outro em sua diferença (Abraão, Melquisedec, Rute). Num diálogo autêntico, os interlocutores devem procurar ultrapassar seus próprios preconceitos históricos e, sobretudo, recusar identificar o que já conhecem de suas tradições com o que pode apresentar qualquer semelhança com o universo próprio do outro. Ou seja, é preciso deixar que o diálogo produza seus próprios efeitos. Não se

${ }^{8}$ GEFFRE, C. "La singularité du christianisme à l'âge du pluralisme religieux", art. cit., p. 355. 
pode começar um diálogo com todas as conclusões traçadas de antemão. Não se pode paralisar um diálogo porque emergiram as diferenças irredutíveis que marcam as diversas expressões religiosas. É isso o que implica respeitar o interlocutor em sua identidade própria. ${ }^{9}$

$2^{\circ}$ Ser fiel a si mesmo, à própria identidade. Aqui reside o paradoxo do diálogo inter-religioso porque conduz a uma tensão inevitável entre a deontologia inerente a todo diálogo e a convicção íntima que o sujeito religioso deve ter de possuir já a verdade. ${ }^{10} \mathrm{O}$ sujeito mesmo deve se definir a partir de certa identidade cultural e religiosa. Se, sob o pretexto da abertura e da universalidade, ele anular sua identidade, isso impossibilitará o diálogo. Sobretudo no contexto atual de indiferentismo e relativismo, o risco de abolir as diferenças irredutíveis deve ser evitado. No caso do diálogo inter-religioso, a fidelidade a si mesmo, à sua própria tradição religiosa, é a condição basilar de um verdadeiro encontro. Isso faz dissipar a ilusão de que seria necessário colocar a fé entre parênteses para melhor encontrar-se com o outro. ${ }^{11} \mathrm{O}$ grande desafio da teologia das religiões reside em aprender a pensar a diferença sem ceder ao relativismo radical.

$3^{\circ}$ Certa igualdade entre os parceiros. É, sem dúvida, aí que reside a maior dificuldade no diálogo entre cristãos e não-cristãos. Não é fácil conciliar o engajamento absoluto que implica a verdade religiosa e a atitude de diálogo e de abertura à verdade dos outros. É essa coexistência difícil que a teologia deve se esforçar para pensar. Para viver a fé numa época de pluralismo religioso e de pluralidade de verdades, é preciso aprender a pensar o absoluto como um absoluto relacional e não como um absoluto de exclusão ou de inclusão. $\mathrm{O}$ cristianismo também não escapa dessa regra. Muitas vezes, no passado, ele confundiu a questão da sua verdade com uma espécie de superioridade em relação às outras religiões. Sem comprometer o engajamento absoluto inerente à fé, é possível considerar o cristianismo como uma realidade relativa, não no sentido de oposição a absoluto, mas no sentido de relacional. A verdade que o cristianismo testemunha não é exclusiva ou inclusiva de qualquer outra verdade, ela é "relativa" ao que é verdade nas outras religiões. ${ }^{12}$ A unicidade do cristianismo pode ser descrita, então, em termos de unicidade relativa e não como uma unicidade de "excelência" ou de "integração". Isso não comprome-

\footnotetext{
${ }^{9}$ Id. "Le fondament théologique du dialogue interreligieux". In: Chemins de dialogue n ${ }^{0} 2,1992$, p. 4.

${ }^{10}$ Id. C.. De Babel a Pentecôte. Paris: Cerf, 2006, p. 110.

${ }^{11}$ Id. "Le fondement théologique du dialogue interreligieux", art. cit., p. 4.

${ }^{12}$ GEFFRE, C. "Le fondement théologique du dialogue interreligieux", art. cit., p. 5.
} 
te sua singularidade entre as outras religiões do mundo. A fé reclamará sempre o engajamento subjetivo absoluto do crente. Mas esse princípio imanente à própria fé, não pode inibir a possibilidade real da prática cordial da alteridade no diálogo com os membros das outras religiões.

Estas são as condições para qualquer diálogo inter-religioso. Um diálogo genérico não existe. O diálogo só pode existir entre pessoas concretas. Isso exige critérios também concretos. Sem essa consideração, sempre pairará sobre o diálogo, notadamente quando provocado pelos cristãos, uma suspeição obscura de pretensa superioridade.

O cristianismo é originariamente relacional. A unicidade da fé cristã reside nessa relacionalidade. Aceitar essa afirmação significa renunciar em insistir numa pretensa racionalidade que tornaria o cristianismo superior às demais tradições religiosas. Assim, aceitar a unicidade do cristianismo como uma unicidade relativa e não como uma unicidade de exclusão ou de integração não compromete sua singularidade própria entre as religiões do mundo. ${ }^{13}$

Uma grande tentação será sempre não respeitar suficientemente a diferença irredutível de cada sistema religioso. O sentido de um sistema religioso deve ser sempre buscado em sua globalidade, não em elementos particulares apenas. Reconhecer certa familiaridade entre as religiões como caminhos de salvação é uma atitude possível. Salvação, no sentido antropológico, se radica no desejo mais profundo do coração humano em buscar uma alteridade, sem pré-julgar a existência ou não dessa alteridade (seja entendida como o Deus pessoal ou como a Realidade última). Isso é insuficiente para compreender as religiões como respostas a um apelo misterioso. ${ }^{14}$

A sedução dos outros caminhos que se apresentam como de salvação é muito forte em nossos dias. Sobretudo os cristãos não adequadamente iniciados na fé ou com uma catequese insuficiente são atraídos por outras experiências religiosas. Há numerosos cristãos ocidentais que buscam as religiões de matrizes orientais, talvez por um desencanto com a modernidade que buscou dessacralizar indiscriminadamente o mundo, ou com uma sociedade de massa nostálgica de uma unidade perdida. ${ }^{15}$ Diante desse quadro, o homem contem-

\footnotetext{
${ }^{13}$ Id. "La singularité du christianisme à l'âge du pluralisme religieux", art. cit., p. 358. Ainda para demonstrar a pertinência de preservar a originalidade cristã num contexto de inevitável pluralismo religioso, o autor apresenta três pistas teológicas para fundamentar o caráter dialogal do cristianismo: o face a face de Israel e da Igreja; o paradoxo da encarnação do Verbo e a dimensão kenótica do cristianismo. Essas pistas serão aprofundas mais adiante em nosso estudo.

${ }^{14}$ Id. "Un salut un pluriel". In: Lumière et Vie, n. 250 - 2001, p. 23.

${ }^{15}$ Id. Ibid., p. 25.
} 
porâneo acaba por buscar uma salvação sem mediações, que seja baseada apenas numa ética cotidiana, pessoal e solidária.

Nas religiões monoteístas a salvação é sempre teosoteria. A salvação não pode ser reduzida apenas a uma espécie de ética do cotidiano. Hoje há uma tendência forte a um agnosticismo voluntário do tipo que afirma que o Absoluto escapa sempre às diversas representações históricas que são feitas dele, como pretendem as religiões. Mesmo para numerosos cristãos, a salvação não está vinculada mais a um apelo vinculante à transcendência. Muitos estão preocupados em buscar uma espécie de sabedoria de vida que os ajude a viver com mais tranqüilidade o dia a dia. Acontece que a salvação ofertada pelas religiões monoteístas não tem somente uma dimensão teologal, mas também escatológica. Nas religiões messiânicas como o judaísmo e o cristianismo, a vida do crente está sob o signo da tensão entre o "já' e o "ainda não" do Reinado de Deus. E mesmo no Islã, que não é diretamente messiânico, a vida correta do homem justo terá sua retribuição no paraíso, além da morte. Nas religiões orientais, percebe-se, sob nuances diversas, uma tensão entre uma salvação intra-mundana e uma extra-mundana. Destaque especial merece o confucionismo chinês. Para este, o caminho da salvação por excelência é a sabedoria: a busca do caminho reto e da bondade. A sabedoria chinesa testemunha um humanismo que respeita o divino sem ligar-se a ele. ${ }^{16}$

Preferimos compreender as religiões como respostas a um mistério que as perpassa e as ultrapassa. Portanto, como algo além de um conjunto de regras de bem viver. Concretamente, porém, essa pretensão é ofuscada pelo contraste que muitas vezes aparece entre o que propõem as religiões e o que elas vivem. Um dos grandes desafios postos às religiões hoje é manter a coerência entre seus programas ideais e a ineficácia prática em socorrer os pobres e as muitas vítimas que temos a nossa volta. Geffré diz que talvez essa seja uma das causas do crescente indiferentismo religioso, especialmente entre os jovens. ${ }^{17}$

Mesmo aceitando a diversidade e as riquezas dos caminhos de salvação que as diversas religiões possuem o cristianismo não pode renunciar à pretensão de ser um caminho diferenciado. Mesmo se tal pretensão parecer insultante para os fiéis das outras religiões, a fé cristã não pode abdicar dela. Como responder adequadamente a esse desafio? Nosso autor propõe enfrentar essa questão da seguinte forma: de um lado, apresentar a herança da fé apostólica

${ }^{16}$ GEFFRÉ, C. "Un salut un pluriel”, art. cit., p. 28.

${ }^{17}$ Id. Ibid., p. 29. 
como fundamento da universalidade da salvação em Cristo; de outro, procurar não justificar essa universalidade como um monopólio do cristianismo. ${ }^{18}$

Em resposta a certa teologia que pretendia reduzir a centralidade da salvação em Cristo, a Declaração Dominus Iesus, de setembro de 2000, repeliu com vigor qualquer tentativa nesse sentido. É certo que é Deus que salva. Mas é Jesus Cristo que é a realização plena da salvação do ser humano. Nele estabeleceu-se a aliança definitiva de Deus e do ser humano e a revelação do desejo eterno de Deus de fazer com que todos os seres humanos participassem da filiação divina de Jesus. Diz a Declaração: "O perene anúncio missionário da Igreja é hoje posto em causa por teorias de índole relativista que pretendem justificar o pluralismo religioso não apenas de fato, mas também de jure \{ou de princípio\}" (DI n.4) ${ }^{19}$. Ora, não se coloca em xeque o perene anúncio missionário da Igreja quando se fala de pluralismo religioso de forma positiva. Por pluralismo religioso quer-se entender o desígnio misterioso de Deus que quer, mediante a diversidade cultural e religiosa da humanidade, expressar a plenitude de sua riqueza. Essa abordagem não conduz inevitavelmente ao relativismo, como afirmam alguns. Ao contrário, saber reinterpretar o núcleo fundamental da fé à luz das exigências e dos desafios de cada contexto histórico sempre foi a condição para que o cristianismo continuasse a ser significativo para as pessoas. É isso o que pede o contexto atual: uma nova reinterpretação da fé cristã. Isso implica em reconhecer que os membros das outras religiões não estão todos esses séculos impermeáveis à revelação divina, enclausurados em seus erros e superstições. Implica também em não afirmar que essa situação se deve a uma espécie de ineficácia da missão cristã. Melhor será ver que o momento atual nos permite reconhecer o pluralismo se coaduna com o que diz o Novo Testamento: que todos se salvem e cheguem ao conhecimento da verdade (1Tm 2,3). Essa vontade divina imutável nos é mais clara hoje do que em outros períodos da história. Essa é a diferença. Por isso, nos é permitido avançar na compreensão e na prática do diálogo.

Mesmo se, ao longo dos séculos, a Igreja procurou reivindicar uma universalidade que não se separasse da de Cristo, nós devemos evitar qualquer identificação entre a universalidade de Cristo e a do cristianismo em suas diversas configurações históricas. Com efeito, é este mesmo princípio da encarnação, quer dizer, da presença do Absoluto de Deus na particularidade histórica de Jesus de Nazaré, que nos conduz a não absolutizar o cristianismo. É esse reconhecimento de sua particularidade histórica que é condição real para o

\footnotetext{
${ }^{18}$ Id. Ibid., p. 31.

${ }^{19}$ CONGREGAÇÃO PARA A DOUTRINA DA FÉ. Declaração Dominus Iesus. Sobre a unicidade e universalidade salvífica de Jesus Cristo e da Igreja. São Paulo: Paulinas, 2000.
} 
diálogo com as outras religiões. Nem os cristãos nem as igrejas são proprietários de Deus ou da sua salvação. São somente testemunhas do Reinado de Deus que chegou em Jesus Cristo e, mediante a ação do Espírito Santo, aos corações dos homens e da história que constroem além das fronteiras da Igreja. ${ }^{20}$

Com efeito, a história humana jamais foi privada da presença do Verbo de Deus e dos dons do Espírito. Ela não é apenas a história da busca tateante de Deus por parte do ser humano, mas também a história da busca do ser humano por parte de Deus. Assim, a teologia cristã pós-conciliar pode afirmar os valores positivos das outras religiões, compreendidos no espírito do que é dito por João Paulo II: "Se não se excluem mediações participadas de diverso tipo e ordem, todavia elas recebem significado e valor unicamente da de Cristo, e não podem ser entendidas como paralelas ou complementares desta." (RM n.5).

Não se pode deixar de perceber que todas as religiões do mundo são cheias de ambiguidades. Alguns de seus elementos estruturantes podem mesmo ser obstáculos à ação da Graça de Deus. Ao mesmo tempo é possível perceber em seus textos fundadores, em seus mitos, em suas práticas ascéticas e místicas, em suas exigências éticas, germes de verdade, de bondade e de santidade, frutos, sem dúvida, da vontade salvadora de Deus. Um critério que pode ser usado para discernir esses germes é perceber nelas tudo o que favorece o descentramento de si e produz uma abertura a uma Alteridade transcendente e a alteridade do outro. Uma experiência religiosa autêntica tem sempre qualquer coisa de pascal, como inspira esse importante texto do Vaticano II: "Com efeito, tendo Cristo morrido por todos e sendo uma só a vocação última do homem, isto é divina, devemos admitir que o Espírito Santo oferece a todos a possibilidade de se associarem, de modo conhecido por Deus, a este mistério pascal" (GS 22).

Aquilo que Geffré chama de o irredutível de cada tradição religiosa pode ser interpretado como manifestação dos valores crísticos disseminados em todas as culturas e religiões pelo Espírito Santo. Não é plausível falar de uma espécie de universalidade englobante, uma simetria acrítica entre as diversas religiões. As diferenças sempre existirão. É melhor falar, segundo Geffré, de valores crísticos que seriam recapitulados no último dia, no mistério de Cristo. ${ }^{21} \mathrm{Um}$ dos objetivos do diálogo inter-religioso é reinterpretar a salvação cristã no face a face com as outras ofertas de salvação. Isso ajudará o cristianismo a melhor desenvolver as virtualidades da salvação cristã para além das suas expressões históricas e tradicionais.

\footnotetext{
${ }^{20}$ GEFFRE, C. "Un salut au pluriel”, art. cit., p. 32.

${ }^{21}$ Id. Ibid., p. 33.
} 


\section{O paradoxo cristológico: Jesus Cristo como o universal concreto}

Todas as religiões têm certa pretensão de universalidade. A diferença cristã é que Jesus Cristo é afirmado como a irrupção de Deus na história. Onde muitos veem um obstáculo para o diálogo inter-religioso, Geffré vê justamente o que pode fundamentá-lo. Por isso busca tirar todas as conseqüências do paradoxo cristológico.

A melhor maneira de manifestar o caráter não totalitário do cristianismo e favorecer o diálogo inter-religioso ${ }^{22}$ é afirmar a centralidade do mistério da encarnação no seu sentido mais realista, recusando-se atribuir lhe apenas um sentido mítico. ${ }^{23}$ A Igreja Apostólica confessa Jesus como o Cristo. Deus revelou todo seu amor para conosco, mediante a humanidade concreta de Jesus. Nele acontece o encontro surpreendente entre a realidade transcendente de Deus e a humanidade. Esse é o traço básico e irrenunciável do cristianismo. Confessamos que a plenitude habita em Jesus, mas esta identificação nos reenvia ao mistério de Deus, que permanece transcendente enquanto se automanifesta a nós. ${ }^{24} \mathrm{O}$ paradoxo absoluto é o mistério de Cristo, inseparavelmente homem e Deus. Existe uma tensão fundamental entre as exigências postas a qualquer diálogo, como a igualdade e a reciprocidade, e a legítima pretensão do cristianismo de ser a religião da manifestação absoluta e definitiva de Deus em Jesus Cristo. Ele não é um mediador entre os outros, ${ }^{25}$ mas a manifestação definitiva de Deus a todos os seres humanos. A originalidade do cristianismo reside nessa identificação de Deus como realidade transcendente a partir da humanidade concreta de Jesus de Nazaré.

Ainda não existe uma resposta teológica satisfatória a esse desafio. Mas uma tentativa dogmaticamente possível deve começar no ponto focal do cristianismo: a confissão de Jesus como o Cristo. Portanto, uma teologia das religiões responsável deve sempre manter a normatividade da cristologia. Claude Geffré não descarta certo inclusivismo, quer dizer, uma teologia da realização

\footnotetext{
22 GEFFRÉ, C. "Le paradoxe christologique comme clé herméneutique du dialogue interreligieux". In: Chemins de Dialogue n. 19 - 2002, p. 172.

${ }^{23}$ HICK, J. A metáfora do Deus Encarnado. Petrópolis: Vozes, 2000. Contestado por Geffré em Crer e Interpretar - a virada hermenêutica da teologia. Petrópolis: Vozes, 2004, p. 117.

${ }^{24}$ GEFFRÉ, C. De Babel à Pentecôte, op. cit., p. 118.

${ }^{25}$ O que vai ao encontro da teologia de Mário de França Miranda quando afirma que a mediação salvífica de Jesus Cristo foi peculiar e única. "Contudo, a fé cristã reafirma que outros reveladores são sempre penúltimos, pois, devido à limitação (estruturalmente) e à pecaminosidade (historicamente) inerentes à condição humana, podem estar a absolutizar não a realidade última, mas projeções de seus próprios interesses. A ação do Espírito Santo em Jesus levou-o a plasmar sua existência na obediência ao Pai e no amor incondicionado a seus semelhantes." Ver desse autor: O cristianismo em face das religiões. São Paulo: Loyola, 1998, aqui p.64-67.
} 
plena em Cristo de todas as sementes de verdade, bondade e santidade contidas nas várias experiências religiosas da humanidade. Seu esforço será reinterpretar esta noção de recuperação de todas as coisas em Cristo num sentido não totalitário. Sem renunciar à confissão de Jesus como o Absoluto, ele prefere dizer que o cristão deve renunciar a toda pretensão de verdade absoluta, precisamente porque confessa Jesus como o Absoluto, ou seja, como plenitude escatológica que não será jamais revelada na história. ${ }^{26}$ Como se vê, Geffré se alinha à corrente predominante no Vaticano II que rejeita um eclesiocentrismo estreito em vista de um inclusivismo cristológico. Nosso autor procura demonstrar a possibilidade real do diálogo inter-religioso a partir da tradição da universalidade da salvação em Jesus Cristo. Sem renunciar a essa confissão fundamental, ele defende a plausibilidade de um inclusivismo constitutivo e de um pluralismo inclusivo que respeitem o irredutível de cada religião como um caminho possível de salvação. Depois do Concílio Vaticano II, a teologia está pronta a reconhecer que as outras religiões também são portadoras de valores salvíficos e que esses valores estão misteriosamente ligados com a única mediação de Cristo (RM 5). Não abrir mão da unicidade da salvação em Cristo e considerar positivamente o que as outras religiões têm de irredutível: eis o grande desafio teológico contemporâneo.

A teologia de Paul Tillich terá uma influência decisiva na abordagem teológica que Geffré fará do cristianismo perante o desafio inevitável do pluralismo religioso. A vigorosa reflexão de Tillich também ressoou na teologia católica, posto que ele manteve a convicção de que para facilitar o diálogo inter-religioso não se pode sacrificar a normatividade cristológica. ${ }^{27} \mathrm{O}$ escândalo da encarnação será a chave hermenêutica utilizada por Geffré para fazer frente a esse desafio.

\subsection{O paradoxo do Logos feito carne}

Geffré não aborda a questão do "como" se deu a encarnação nem especula sobre a união hipostática. Ele prioriza dirigir a atenção para o sentido soteriológico deste mistério. Sem dúvida, o escrito onde mais aprofunda sua compreensão do mistério da encarnação é o artigo que se apóia nas reflexões em Paul Tillich. ${ }^{28}$ Opta por assumir as intuições do grande teólogo protestante, especialmente quando ele fundamenta o movimento do Logos encarnado, que

\footnotetext{
${ }^{26}$ GEFFRE, C. De Babel à Pentecôte, op. cit., p. 83.

27 GEFFRE, C. "Paul Tillich et l'avenir de l'oecuménisme interreligieux." In: Revue des Sciences Philosophiques et Théologiques 77 (1993), p. 5

${ }^{28}$ Id. Ibid., p. 3-21.
} 
realiza a identidade entre o absolutamente universal e o absolutamente concreto. Esse paradoxo do Logos se assemelha ao paradoxo do cristianismo como religião da revelação final.

A premência do diálogo inter-religioso nos conduz a refletir mais profundamente como uma particularidade histórica (Jesus de Nazaré) pode ao mesmo tempo ter um alcance universal (o Cristo salvador de todos os homens). O problema se desdobra quando passamos da consideração da universalidade de Cristo para a universalidade do cristianismo. Uma distinção fundamental a ser feita, desde já, é entre a particularidade do cristianismo como concreção histórica e a particularidade de Cristo como Mediador absoluto na história. Essa linha entre a presença plena de Deus na pessoa contingente de Jesus Cristo será sempre o escândalo da pretensão cristã aos olhos das outras tradições religiosas. $^{29}$

O autor francês serve-se do conceito de paradoxo, a partir da noção tillichiana, que o entende como um acontecimento que transcende a experiência humana ordinária e suas expectativas. ${ }^{30}$ Então, o paradoxo em teologia não é contrário a uma exigência de racionalidade lógica. $\mathrm{O}$ paradoxo não contém uma contradição lógica, mas um fato que transcende a todas as possibilidades humanas. Tillich considera que o acontecimento da encarnação é único, pois possibilita a relação entre Deus e o homem, ou, como expressa o quarto Evangelho, o Logos se fez carne, que dizer, concretizou a presença de Deus. Ou seja, a pessoa de Jesus Cristo concretiza uma realidade transcendente numa existência histórica, num tempo e espaço determinados. O Logos, princípio da automanifestação de Deus no universo e na história, assume a existência de um ser humano. Esse é o paradoxo por excelência. Todas as outras determinações no interior do cristianismo são variações e aplicações desse paradoxo, por exemplo, a doutrina da justificação pela graça ou a da participação de Deus no sofrimento do universo. ${ }^{31}$

A tensão entre o particular e o universal, entre o finito e o infinito é constante. Daí a centralidade do paradoxo da mensagem cristã: nós confessamos Jesus de Nazaré como o Cristo. Isso quer dizer que, na vida pessoal de Jesus, a essência do ser humano apareceu sob as condições da existência (finitude, caducidade, alienação, ambiguidade etc), sem ser vencida por elas. ${ }^{32}$

\footnotetext{
${ }^{29}$ Id. C. De Babel à Pentecôte, op. cit., p. 85.

${ }^{30}$ Id. Ibidem, apud: Tillich, P. Systematic Theology, vol . 1. University of Chicago Press, 1951, p. 57.

${ }^{31}$ GEFFRÉ, C. De Babel à Pentecôte, op. cit., p. 86, apud: Tillich, P. Systematic Theology, vol. 3. University of Chicago Press, 1963, p. 284. Essa mesma fundamentação é mencionada no artigo já citado "Paul Tillich et l'avenir de l'oecuménisme interreligieux", p. 7.

${ }^{32}$ Id. "Le paradoxe christologique comme clé herméneutique du dialogue interreligieux", art. cit., p. 173, apud Tillich, P. Systematic Theology, vol . 2, p. 94.
} 
Geffré adota a distinção que Tillich faz entre essência, existência e alienação: toda existência histórica comporta uma alienação (estrangement) com respeito à verdadeira essência humana. Na pessoa de Jesus, confessado como o Cristo, se manifestou o Novo Ser (New Being), cuja função essencial é salvar o ser humano de sua alienação e renovar toda a criação. ${ }^{33}$ Tillich alça $o$ conceito de Novo Ser à condição de norma material de toda teologia sistemática. ${ }^{34}$ Ao falar em Cristo como o Novo Ser, Tillich tem em mente a doutrina paulina da submissão a Cristo de todas as forças cósmicas. Assim, este teólogo mantém distância do paulinismo dos primeiros reformadores, que priorizava a doutrina da justificação pela fé. Tillich busca alinhar se mais com a doutrina tradicional dos Padres da Igreja sobre o Leigos universal e sobre as "sementes do Verbo" espalhadas em toda a criação. ${ }^{35}$ Ele coloca esse princípio como fundamental para toda teologia cristã das religiões. ${ }^{36}$ Se Cristo é o absolutamente concreto, então, de certa maneira, o cristianismo como religião particular, já está implicado nas outras religiões. E estas são manifestações particulares do Logos universal. ${ }^{37}$

Utilizando ainda o conceito tillichiano de Novo Ser, Geffré afirma que se Jesus é confessado como o Cristo, então ele se identifica com o Logos, e mais, ele é a linha de identidade entre o absolutamente concreto e o absolutamente universal. A palavra "carne" não designa só uma substância material, mas a existência histórica de um homem. ${ }^{38} \mathrm{Na}$ medida em que ele é o absolutamente concreto, a ele concerne toda a existência concreta; e na medida em que ele é o universal, a relação com ele inclui potencialmente todas as relações possíveis. Com esse argumento, nosso autor pretende colocar um fundamento neotestamentário nesta identidade do universal e do concreto a partir das Car-

\footnotetext{
${ }^{33}$ Id. "Paul Tillich et l'avenir de l'oecuménisme interreligieux", art. cit., p. 8.

${ }^{34}$ Id. Ibid., p. 8, apud: Tillich, P. Systematic Theology, vol . 1, p. 48.

${ }^{35}$ Essa doutrina patrística tradicional que foi recuperada pelo concílio Vaticano II vem sendo usada como um fundamento sólido para o diálogo inter-religioso visto a partir da ótica cristã. Geffré também dá grande importância a essa doutrina, como demonstramos ao tratar dos fundamentos teológicos para o diálogo propostos por ele. Recentemente, o Papa Bento XVI pronunciou um discurso em que também recorda a doutrina das "sementes do Verbo", atribuída a Justino, apologista do século II. Muitos, na ocasião, viram esse discurso como mais um freio colocado pelo Romano Pontífice no processo de diálogo entre as religiões. Remetemos à íntegra desse texto recebido com gáudio pelos que se opõem ao diálogo entre as religiões, o que defendemos neste estudo não somente possível, mas necessário. Disponível em http://www.vatican.va/holy_father/benedict_xvi/audiences/2007/documents/hf_benxvi_ aud_20070321_po.html acesso em 02/05/2007.

${ }^{36}$ GEFFRÉ, C. "Paul Tillich et l'avenir de l'oecuménisme interreligieux", art. cit., p. 9, apud:

Tillich, P. Systematic Theology, vol . 1, p.16-17.

${ }^{37}$ Id. De Babel à Pentecôte, op. cit., p. 89

${ }^{38}$ Id. Ibidem.
} 
tas paulinas, especialmente 2 Cor 5,17, quando faz referência ao Novo Ser em Cristo, e em Rm 8,22 quando evoca a submissão escatológica de todas as forças cósmicas ao Cristo

Geffré junta ainda ao pensamento de Tillich as intuições de Nicolau de Cusa. Afirma o nosso autor que a bela fórmula de Nicolau de Cusa serve bem para desenvolver todas as implicações do mistério de Cristo considerado como universal concreto. Depois dos tempos apostólicos, os cristãos confessaram Jesus como o Cristo. Isso veio significar que Jesus nos revelou o amor universal de Deus por todos os seres humanos não somente por sua mensagem, mas na e por sua humanidade concreta. Então, o "universal" é o amor de Deus para com todos os seres humanos e o "concreto" é a humanidade de Jesus. Foi na humanidade de Jesus que "habitou toda a divindade" e por ela nos foi revelado o incomensurável e universal amor de Deus. Jesus é a figura concreta do absoluto amor de Deus por todos nós. É no evento da Encarnação que acontece o encontro inédito entre o absoluto e a história, a união paradoxal entre o universal e o concreto.

O universal que não se enraíza no particular é um universal abstrato e que não tem muito interesse. Toda a questão está em saber qual é o particular que pode ter um alcance universal. Isso é capital para a compreensão de toda a problemática. Quando se diz que o cristianismo professa a fé na encarnação de Deus, ele se apresenta como a religião que possui o máximo do que Paul Tillich chamava da união paradoxal do universal com o particular. Esta união é a eterna questão que está no coração da fé: o encontro do absoluto e da história. Filosoficamente é um grande e velho problema. Do ponto de vista teológico, pode-se simplesmente aderir à incondicionalidade da fé, e assim aceitar o extraordinário do absoluto na história, o encontro da eternidade e do tempo na pessoa de Jesus Cristo. Ao mesmo tempo em que se pode mostrar que essas afirmações da fé cristã podem também ser compreendidas por analogia com o que acontece com certos elementos culturais, que também transcendem sua particularidade e alcançam um valor universal. Geffré chama esses valores de o humano autêntico. Seja qual for sua origem étnica ou geográfica, se esses valores colocam em relevo a dimensão fundamental do ser humano, têm o que dizer a todas as culturas. ${ }^{39}$ Algo análogo aconteceu com o fato da Encarnação do Logos, onde um acontecimento particular assumiu dimensões universais.

Geffré afirma que a cristologia deve evitar cair na mera especulação. Somente à luz da teologia da cruz é possível vislumbrar o paradoxo de Jesus Cristo absolutamente concreto e universal. Isso será de vital importância para a desabsolutização do cristianismo enquanto religião histórica. No diálogo

${ }^{39}$ GEFFRÉ, C. Profession Théologien, op. cit., p. 98-99. 
com as outras religiões, o cristianismo deveria renunciar a uma unicidade de excelência em vista de uma unicidade singular e relativa.$^{40} \mathrm{~A}$ cruz é a condição da glória. A renúncia a uma particularidade é a condição de uma universalidade concreta. ${ }^{41}$ Segundo nossa capacidade humana de conhecer, a humanidade particular de Jesus não pode ser a tradução adequada das riquezas contidas na plenitude do mistério do Cristo. Se isso fosse possível, Cristo não seria mais o ícone de Deus, mas um ídolo. ${ }^{42}$ Para Geffré, Jesus é o ícone, pois aponta para além dele mesmo. Esse é um aspecto fundamental para a cristologia dele. Ícone é o elemento material organizado de tal forma que visibilize o representado sem, contudo, esgotar-lhe todo o significado. O ícone sempre deixa aberta uma possibilidade de interpretação a quem o contempla. Essa dimensão icônica da humanidade concreta de Jesus remete sempre para além dela mesma. Considerar Cristo como ícone de Deus é um elemento fundamental na cristologia de Geffré:

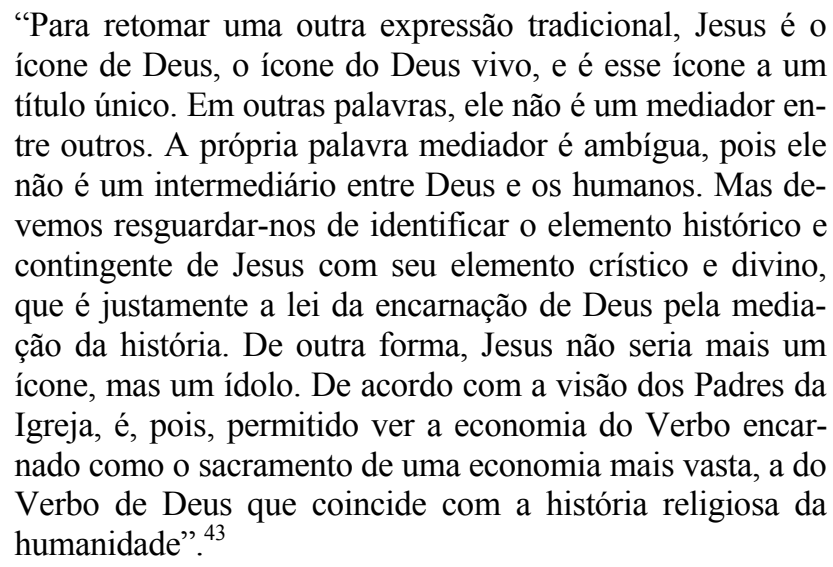

Por isso, o cristianismo não pode excluir outras maneiras de identificar o mistério de Deus. O teólogo francês tem consciência que se move num terreno delicado, pois se por um lado ressalta com força a distinção entre a hu-

\footnotetext{
${ }^{40}$ Aqui Geffré faz referência à obra St. Breton, Unicité et monothéisme, Paris: Cerf, 1981 como a fonte de onde ele retira essa noção de "unicidade relativa", entendida como relacional.

${ }^{41}$ GEFFRÉ, C. "Paul Tillich et l'avenir de l'oecuménisme interreligieux ", art. cit., p. 10. O autor recorre à intuição de Tillich de que o Cristo é, ao mesmo tempo, "Jesus" e a "negação de Jesus". Ou seja, que Jesus, como homem historicamente situado, sacrificou-se a si mesmo em vista do Cristo. Assim, a cruz tem um valor simbólico universal. Também exprime essas idéias em termos semelhantes em De Babel à Pentecôte, op. cit., p. 90; 121.

${ }^{42}$ Id. De Babel à Pentecôte, op. cit., p. 118.

${ }^{43}$ GEFFRÉ, C. Crer e Interpretar - a virada hermenêtica da teologia, op. cit., p. 164-165.
} 
manidade de Jesus e sua divindade, por outro pretende manter a união indissolúvel entre ambas, sem se afastar da declaração dogmática de Calcedônia. ${ }^{44}$ Distanciando-se de Raimundo Panikkar, Geffré rechaça toda separação entre o Verbo e Jesus. Afirma que a tentação de afirmar um Cristo cósmico em torno do qual gravitariam todas as religiões é muito perigosa. É melhor tirar todas as conseqüências da encarnação do Verbo. ${ }^{45}$

Então Cristo e Jesus são exatamente a mesma pessoa. A pessoa de Jesus, como manifestação histórica do Logos invisível e universal, realiza a identidade entre o absolutamente universal e o absolutamente concreto. $\mathrm{O}$ paradoxo consiste em que o Cristo, como ser plenamente histórico, está numa união indefectível com Deus, enquanto que a história está sob o signo da alienação com Deus. De alguma maneira, a partir do sacrifício da particularidade de Jesus de Nazaré, de sua morte na cruz, Jesus renasce como o Cristo. A ressurreição restitui misteriosamente a historicidade de Jesus, unindo-a à universalidade do Cristo. O crucificado renasce numa dimensão universal, agora liberto de um particularismo que o faria refém da contingência de sua existência histórica anterior. $\mathrm{O}$ ressuscitado não é refém de sua existência anterior, embora tenha nela sua condição de possibilidade. A carne é o lugar do encontro definitivo do divino e do humano. Esse encontro acontece em Jesus Cristo, o Novo Ser.

\subsection{Cristo é a plenitude da revelação}

A abordagem que Geffré faz do paradoxo cristológico leva-o a apresentar a pessoa de Cristo como plenitude da revelação: Cristo é a revelação de Deus e a revelação final.

O paradoxo da encarnação traz à luz a plenitude da automanifestação de Deus. Jesus pode ser reconhecido como a figura do amor absoluto de Deus. Como Deus não pode se manifestar a não ser em termos divinos é na contingência humana de Jesus que deve ser reconhecido. Essa é a situação paradoxal

\footnotetext{
${ }^{44}$ BARA, S. B. "Unicidad de Cristo y singularid del cristianismo ante el desafío del pluralismo religioso, segun Claude Geffré”. In: Estudios Eclesiásticos (81), 2006, p. 112.

${ }^{45}$ GEFFRÉ, C. Crer e interpretar, op. cit., p. 165-166. O mesmo distanciamento de Panikkar aparece em Profession Théologien, op. cit., p. 146-148. Geffré procura manter-se fiel à fé eclesial expressa no dogma cristológico de Calcedônia, reforçado em pronunciamentos recentes do Magistério acerca dos cuidados inerentes ao diálogo inter-religioso no tocante a singularidade de Cristo. Cf. RM n. 6, bem como DI n. 10, onde se afirma não ser possível desvincular o Verbo e Jesus Cristo, ou a ação salvífica do Logos da ação do Verbo encarnado.
} 
da encarnação. ${ }^{46}$ Ou seja, Deus não absolutiza uma particularidade. Como nenhuma particularidade histórica é absoluta, em virtude mesmo dessa relatividade, Deus pode aliar-se sempre à nossa história real. ${ }^{47}$ É na situação concreta do ser humano que Deus se revela. O acontecimento Jesus Cristo condensa e exprime definitivamente essa chegada de Deus à realidade humana. Ao mesmo tempo em que sedimenta essa certeza, Geffré sustenta que, enquanto conteúdo inteligível, a revelação continua aberta aos possíveis da história humana, como lugar de perguntas e respostas. A revelação está concluída com o acontecimento Jesus de Nazaré, mas, como plenitude da verdade, ela jamais cessa de manifestar suas virtualidades para a inteligência humana. ${ }^{48}$

Estabelece-se, então, uma distinção entre plenitude qualitativa e quantitativa. Jesus Cristo é a revelação definitiva e insuperável da revelação de Deus, mas nossa percepção desse acontecimento é limitada por nossa contingência histórica, logo, ela pode ser reinterpretada até que chegue a consumação escatológica. ${ }^{49}$ Embora trabalhe com conceitos pouco precisos, não é intenção de Geffré negar o caráter completo e definitivo da revelação de Deus em Jesus Cristo ou considerar que essa revelação necessite ser completada pelo conteúdo das outras religiões. O que ele afirma de fato é que o conteúdo da verdade cristã moldurado pela linguagem humana é limitado. Por isso necessitará sempre ser reinterpretado. ${ }^{50}$

A intenção de Geffré é abrir espaço para o reconhecimento de experiências reveladoras também em outras religiões. Por isso sustenta que a revelação cristã não esgota a plenitude do mistério de Deus. Este pode ser enriquecido por outras experiências religiosas da humanidade. Disso não se pode concluir que ele ceda a qualquer diminuição da singularidade de Cristo como verdade

\footnotetext{
46 GEFFRÉ. C. "Le paradoxe christologique comme clé herméneutique du dialogue interreligieux", art. cit., p. 173. Também "Le fondement théologique du dialogue interreligieux", art. cit., p. 98 .

${ }^{47}$ DUQUOC, Ch. Dieu Différent. Paris: Cerf, 1978, p. 143.

${ }^{48}$ GEFFRE, C. Profession Théologien, op. cit., p. 141.

${ }^{49}$ Entramos aqui em mais um terreno alagadiço na teologia de Geffré. A distinção entre revelação qualitativa e quantitativa pode levar a equívocos. Se for sustentado excessivamente que a revelação de Deus em Jesus Cristo, por ser limitada pela contingência histórica dele, pode ser "completada" por outras "revelações", a singularidade de Jesus fica seriamente ameaçada. A percepção limitada que temos do acontecimento Jesus Cristo não pode nos levar a concluir que "falte" algo à revelação que ele faz de Deus. Esses conceitos parecem levar a essa confusão. Não cabe separar revelação plena e verdade total do acontecimento da revelação, mesmo se o acesso a essa verdade só possa se dar a partir do horizonte histórico que dispomos (DI 6).

${ }^{50}$ GEFFRE, C. "L'avenir du dialogue interreligieux aprés Dominus Iesus". In: Sedos Bulletin 34 (2002), p. 133. A mesma argumentação aparece em "Le fondement théologique du dialogue.." p. 98-99. Também em "Le paradoxe christologique comme clé herméneutique du dialogue interreligieux", art. cit., p. 174.
} 
absoluta. Ele sustenta que todas as manifestações de Deus na história, antes ou depois da Encarnação, se deram em referência à manifestação definitiva de Jesus como o Cristo. Jesus Cristo é a irrupção definitiva de Deus na história. ${ }^{51}$ Depois que o Verbo se fez carne em Jesus de Nazaré, depois do mistério de sua páscoa, a história humana adquiriu um sentido completamente novo. Há uma "revelação imanente" que perpassa toda a história humana. A revelação histórica que coincide com a história de Israel e com a consumação da Nova Aliança se converte em sacramento dessa busca do ser humano por Deus e de Deus pelo ser humano. As outras religiões seriam objetivações dessa única vontade salvífica universal de Deus. Suas potencialidades reveladoras ou salvíficas se devem a essa presença escondida do mistério de Cristo nelas. ${ }^{52}$ Presença que se torna manifesta pela ação do Espírito Santo, que não é outro senão o Espírito do Cristo ressuscitado. Cabe ao Espírito Santo tecer os fios da história humana como história da revelação e da salvação em um dinamismo tal que oriente a história toda ao seu ponto culminante: o acontecimento Jesus Cristo, em que o ser humano chega plenamente a si mesmo e plenamente a Deus. Nessa direção também apontam os documentos recentes do Magistério, quando reforçam a inseparabilidade da ação do Espírito e da ação de Cristo, já que se trata de uma só economia salvífica (LG 3-4; GS 22; RM 5 e 28; DI 7 e 12).

É essa ação universal do Espírito que fundamenta o conceito de cristianidade, para significar essa realidade da presença escondida do mistério de Cristo nas diversas culturas e religiões. Cristianidade implica em certo jeito crístico de ser que se estende para além das fronteiras do cristianismo histórico. É uma espécie de onipresença do Espírito de Cristo em todo ser humano. Como Espírito de Cristo, ele não é outro senão o Espírito de Deus que sopra sobre os homens, intimamente ligado à história da humanidade. ${ }^{53}$

Esta certa maneira crística de ser, essa potencialidade cristã, seria como uma dimensão antropológica universal, posto que, desde o ponto de vista cris-

\footnotetext{
${ }^{51}$ GEFFRÉ, C. Profession Théologien, op. cit., p. 113-114.

${ }^{52}$ GEFFRÉ, C. "Paul Tillich et l'avenir de l'oecuménisme interreligieux", art. cit., p. 11. Nosso autor assume em sua reflexão a distinção que Karl Rahner fez entre revelação "categorial", que coincide com o fenômeno histórico da revelação bíblica, e revelação "transcendental", que é coextensiva à história espiritual da humanidade - a autocomunicação de Deus à consciência humana.

${ }^{53}$ GEFFRE, C. Profession Théologien, op. cit., p. 50-51. Também em De Babel a Pentecôte, op. cit., p. 291 o autor retoma este conceito neste mesmo sentido. Mário de França Miranda considera importante para o contexto atual essa dimensão universalizante intrínseca à fé cristã, que Geffré chama cristianidade. Este elemento é relevante porque deixa transparecer claramente a impertinência de qualquer tentativa de retorno a uma cristandade uniformizadora. Dimensão universalizante da fé não pode se confundir com absolutização do cristianismo. Cf. França Miranda, M. "Religiões particulares e paz universal. A contribuição cristã". In: Atualidade Teológi$c a \mathrm{n}^{\circ} 23$, maio/agosto 2006, p. 194.
} 
tão, o ser humano não foi criado somente à imagem de Deus, mas à imagem daquele que por excelência é a plenitude mesma do ser humano: Jesus Cristo. Essa marca crística está efetivamente em todo ser humano, mesmo fora do cristianismo. Cada ser humano tem como que uma "disposição congênita" para referir-se a Jesus Cristo em sua abertura à transcendência e à existência humana. A vocação fundamental do ser humano é, então, ser introduzido na vida divina. ${ }^{54}$ Jesus, como o ponto de encontro concreto e definitivo entre o transcendente e o histórico, é o fundamento do que Geffré chama de cristianidade. Trata-se, sem dúvida, de uma maneira sensata de perceber a presença escondida do mistério de Cristo co-extensivo a todos os momentos da história. ${ }^{55}$ Ele prefere falar de valores crísticos presentes nas diversas culturas e religiões, do que de valores implicitamente cristãos que encontrariam seu cumprimento no cristianismo histórico. A grandiosidade do mistério de Cristo não encontrou sua tradução adequada nos diversos cristianismos históricos que conhecemos. Por isso, as outras religiões podem misteriosamente encarnar certos valores crísticos e até mesmo ajudar o cristianismo a explicitar melhor algumas virtualidades do mistério de Cristo, do qual ele é portador pleno. ${ }^{56}$

Em todo ser humano está inscrito o desejo do Absoluto. É essa busca comum de Deus que pode ser o ponto de partida para um diálogo interreligioso fecundo. Da busca sincera do Absoluto passa-se à busca do que é mais profundo na existência humana. Esta relação autêntica com o mistério capacita o sujeito religioso a um relacionamento autêntico com os outros. Uma autêntica experiência religiosa seria marcada pela busca do que é autenticamente humano como condição de experienciar o autenticamente divino. Esse caminho ao autenticamente humano é apontado por Geffré como um critério decisivo para o diálogo inter-religioso. ${ }^{57}$

Cristo não somente dá sentido à história, mas a conduz: ele está no centro da história como acontecimento definitivo de salvação. ${ }^{58}$ No entanto, isso se dá a partir da história, não a despeito dela. Manifestar-se na particularidade histórica de Jesus de Nazaré é, finalmente, uma escolha livre de Deus. Dito de outra forma, nenhuma manifestação histórica de Deus, nem mesmo o Logos encarnado, pode ser absolutizado. Admitir o contrário disso seria quase que esbarrar no docetismo e não considerar seriamente a humanidade de Jesus. Não podemos identificar o elemento histórico e contingente de Jesus e seu

\footnotetext{
${ }^{54}$ Id. Profession Théologien, op. cit., p. 134.

${ }^{55}$ Id. Ibid., p. 147-148. Aqui Geffré assume que toma o conceito cristianidade das reflexões de Raimundo Panikkar em Invitación a la sabiduría. Madrid: Espasa, 1998, p. 169.

${ }^{56}$ GEFFRÉ C. Crer e interpretar, op. cit., p. 160.

${ }^{57}$ Id. "Pour un christianisme mondial". In: RSR 86/1 (1998), p. 61.

${ }^{58}$ Id. De Babel à Pentecôte, op. cit., p. 112.
} 
elemento crístico e divino, embora eles nunca se separem. A humanidade de Jesus é o elemento concreto (o ícone) pelo qual, pela fé, se tem acesso a Deus como Absoluto. "Só o Deus de Jesus é o Absoluto, ao mesmo tempo em que a fé cristã atesta que em Jesus, e somente nele, o Absoluto se manifestou de maneira única e definitiva". ${ }^{59} \mathrm{O}$ liame nunca rompido entre o absoluto e o particular na pessoa de Jesus, confessado como o Cristo, sempre nos remete a um Deus transcendente, que escapa a toda identificação. É justamente isso que é paradoxal no cristianismo. Essa desabsolutização de Jesus e dos diversos cristianismos históricos é o que permite não excluir a priori a possível manifestação das riquezas do mistério de Deus nas outras tradições religiosas.

Abrir-se ao diferente é, portanto, inerente à fé cristã. $\mathrm{O}$ cristianismo já nasce confessando a alteridade de um Deus que é sempre maior, que vai sempre além do que podemos apreender dele. A identidade cristã não se define como uma perfeição já conquistada, mas em termos de devir, de consentimento ao outro e de serviço fraterno. ${ }^{60}$

Continuando o caminho aberto pelo Vaticano II e por Documentos como Redemptoris Missio e Diálogo e Anúncio, devemos prosseguir na busca de um olhar positivo sobre as outras religiões e até mesmo reconhecê-las como possíveis mediações de salvação para seus membros. No entanto, isso não deve nos impedir de permanecermos conscientes de que graves ambiguidades as afetam. Um discernimento adequado é sempre preciso. Diz nosso autor:

Não somente todas as religiões não são equivalentes, mas no interior de cada religião não são todos os seus elementos constitutivos que favorecem a abertura para o Absoluto e a prática da justiça em seu sentido de Reino de Deus, que nos foi revelado em Jesus Cristo. ${ }^{61}$

O cristianismo pode afirmar sua singularidade de forma não totalitária, ainda que seja o portador da revelação final. ${ }^{62}$ É possível uma articulação coerente entre a pretensão de cada religião em revelar o Absoluto e a do cristianismo em ser a religião da revelação final. O cristianismo é portador de um caminho concreto de salvação, porém não pode absolutizar esse caminho, precisamente por ser a religião da revelação final. Essas considerações permitem desmistificar as pretensões das religiões particulares, inclusive o cristia-

${ }^{59}$ Id. "O lugar das religiões no plano da salvação". In: Teixeira, F. (org.) O diálogo interreligioso como afirmação da vida. São Paulo: Paulinas, 1997, p.126.

${ }^{60}$ Id. De Babel à Pentecôte, op. cit., p. 123.

${ }^{61}$ Id. "O lugar das religiões no plano da salvação", art. cit., p. 129.

${ }^{62}$ GEFFRÉ, C. "O lugar das religiões no plano da salvação", art. cit., p. 11. 
nismo. No entanto, elas também nos convidam a compreender e respeitar o engajamento e a adesão incondicional que requer cada religião, sem cair no relativismo. Em nenhum momento Geffré cogita cair numa espécie de relativismo histórico. A comunidade eclesial terá sempre salvaguardada sua função normativa. Ou seja, sem a comunidade eclesial, a plena revelação de Deus em Jesus Cristo, o Novo Ser, não seria acolhida, vivenciada e transmitida. A comunidade eclesial é o lugar da "síntese criativa" entre o caminho concreto de salvação que ela propõe e os outros caminhos propostos pelas outras religiões, exercitando um adequado discernimento. ${ }^{63}$

O futuro do movimento ecumênico e inter-religioso dependerá da maneira como cada religião ficar aberta à crítica da religião em nome da própria religião. Assim será possível a cada religião ultrapassar a tentação de dobrar-se sobre si mesma e de autoabsolutizar-se, permanecendo aberta ao diálogo. ${ }^{64}$ Essa abertura à autocrítica é também importante para a Igreja católica, sobretudo no que se refere a seu dever missionário. Se, de fato, absoluta for somente a revelação final como plenitude do Reino de Deus, nem o cristianismo, nem a Igreja são absolutos. Nesse sentido, a missão da Igreja há que se concentrar mais no testemunho do Reino do que numa busca de conversão dos nãocrentes às fileiras eclesiásticas.

\section{Conclusão}

A pretensão do cristianismo como religião da manifestação definitiva de Deus em Jesus Cristo, nunca deve ser colocada entre parênteses no processo de diálogo inter-religioso. Por isso mesmo esse diálogo se dará sempre sob essa tensão entre o que afirma de maneira irrevogável o cristianismo e o que afirmam também de forma convicta as outras religiões. O esforço da teologia cristã das religiões visa demonstrar o caráter não totalitário do cristianismo. Os argumentos sólidos apresentados mostram que o cristianismo é estruturalmente dialogal.

A novidade da reflexão teológica de Geffré é exatamente começar o diálogo a partir de Jesus Cristo, tomando outra direção daquela que outros teólogos contemporâneos. Ou seja, ele não parte em primeiro lugar do teocentrismo para depois chegar a Jesus como revelação última de Deus, mas prefere tirar todas as consequências desta centralidade de Jesus, compreendendo melhor sua singularidade. Pode-se dizer que ele se afina com o modelo inclusivista em sua teologia das religiões, colocando novos matizes, até configurar algo

${ }^{63}$ Id. "Révélation, écriture et tradition dans la Dogmatique de 1925", art. cit., p. 213.

${ }^{64}$ Id. "Paul Tillich et l'avenir de l'oecuménisme interreligieux", art. cit., p. 20. 
como um "pluralismo-inclusivo", que mantém um cristocentrismo constitutivo, ao mesmo tempo em que reconhece os valores próprios das outras religiões. É certo que uma séria teologia cristã das religiões não pode prescindir da normatividade cristológica. É o centro mesmo da mensagem cristã, a saber, a manifestação de Deus na particularidade histórica de Jesus de Nazaré, que tem a força necessária para exorcizar qualquer pretensão autoritária e abrir-se sem medo ao diferente. À medida que assume sua historicidade, o cristianismo necessariamente reconhece o imperativo do diálogo.

A partir do que foi exposto, resta-nos continuar o aprofundamento da pesquisa teológica em vista de uma melhor articulação entre o irredutível da singularidade cristã e o irredutível das outras religiões. A fé cristã sustenta que é nesse caminho concreto de salvação inaugurado por Jesus Cristo que encontramos a revelação final de Deus sobre o mundo, sobre o ser humano. Porém essa afirmação também precisa deixar em aberto a questão de saber se essa revelação final pode ser estendida às outras religiões. ${ }^{65}$

\section{Résumé}

Le dialogue inter-religieux, dans la position de Caude Geffré, est toujours une proposition sérieuse. Malgré le christianisme ne doive pas se présenter come la religion absolue, ne peut pas aussi être placé dans une situation secondaire. La figure de Jésus-Christ est centrale pour le dialogue chrétien et avec cela, il faut d'abandonner l'autoritarisme religieux, mais de conserver l'essieu de la foi chrétienne.

Carlos Antonio da Silva

Doutor em Teologia pela PUC-Rio com tese sobre Claude Geffré.

${ }^{65}$ GEFFRÉ, C. “Paul Tillich et l'avenir de l'oecuménisme interreligieux”, art. cit., p. 13. 